DOI: doi.org/10.18372/38221

UDC: $656.078 .12: 504.1$

\title{
3.4 ECOLOGICAL APPROACH TO EVALUATION OF THE EFFECTS OF TRANSPORT ON ENVIRONMENT IN INTERMODAL TRANSPORTATION
}

\author{
Viktoria Khrutba ${ }^{1}$,Vasyl Mateichyk ${ }^{l}$, Oksana Spasichenko ${ }^{I}$, Svitlana Marunych ${ }^{2}$
}

In modern conditions of globalization of the economy, most of the international transportation is carried out with the participation of two or more modes of transport in mixed traffic (in different combinations) on the «door to door» principle. The Association Agreement between Ukraine and the EU provides for the development of multimodal transport as one of the areas for the creation of a stable, efficient and safe transport system integrated with the TransEuropean Transport Network TEN-T. In Europe, in recent years, two thirds of international traffic has been carried out in mixed traffic. The Po-Po (roll-on roll-off) technology has become the most widespread. Promoting the development and formation of a flexible national policy on mixed freight and developing multimodal and intermodal transportation is a promising direction for the development of the Ukrainian transport system, as it forces us to search for new ways of solving non-standard transportation issues, and constantly develop and implement new technologies for the transportation process. A rational combination of different types of transport can significantly reduce the total cost and time of transportation, increase the volume of cargo and the number of passenger traffic with the participation of national transport companies, increase the country's competitiveness in the world transport services market, develop the network of existing transport corridors, integrate Ukraine's transport infrastructure into the world transport system [1].

In this connection, requirements for the quality of supply of goods are increased, changes are made in the choice of modes of transport, and progressive forms of cargo delivery are introduced. All this leads to changes in the structure of transportation and, in fact, to a new logistical view of transport and the revision of transport policy in the direction of creating an optimal logistics system, reducing the delivery time, improving the quality of goods, reducing the transport costs of the consumer. Underestimation of the role of logistics as a factor of influence on the efficiency and competitiveness of the country's economy worsen the position of our state in international rankings. In 2016, Ukraine ranked 80th in the world by the index of global competitiveness and ranked 85 th in the index of logistic efficiency.

Logistic transport processes, which are an integral part of both production processes and consumption, have a significant human-induced environmental impact. This is largely due to the use of vehicles for the provision and movement of material resources and / or finished products in the logistics chain. At the same time, the requirements for preservation of the environment are constantly increasing, so companies in transport should consider the external costs associated with climate change, air pollution, waste, noise, vibration and accidents. Environmental pollution and irrational use of natural resources potential in the implementation of passenger and freight transport lead to a disturbance in the balance of natural ecosystems, exacerbate the ecological crisis, which is accompanied by a crisis of socio-economic system at the global level [2].

World experience shows that the minimization of environmental impacts in the system of transport logistics requires the use of conceptually new approaches and management methods to mobilize reserves to increase environmental and economic efficiency and ensure the transition from quantitative consumption to more qualitative, harmonization of economic, social and environmental interests of the economy. Consequently, systematic research and substantiation of the need for ecologically-oriented management of intermodal transport in order to create an environment in which the needs of the population are provided, the efficiency of delivery of passengers or goods is increased, and the condition for minimizing the negative consequences of anthropogenic interference in the ecosystem is achieved. 
The purpose of the work is to develop the basic principles of ecological logistics in intermodal transportation in order to reduce the impact of transport activities on the environment.

To achieve this goal, the following tasks were formed:

- to characterize the implementation of inter / multimodal transportation;

- to determine the peculiarities of the use of aviation and motor transport in intermodal transportation and its impact on the environment;

- to analyze the existing approaches to the formation of logistics systems on the principles of minimizing the environmental impact;

- to form the basic principles of the formation of an ecologically oriented logistics system for intermodal transportation.

The object of research is the processes of forming logistics systems while ensuring minimization of negative environmental impact.

The subject of the study is a set of theoretical, methodological and practical provisions for the optimization of logistics processes in intermodal transport by aviation and motor transport.

In the modern world, there is a concept that the effectiveness of international trade, economic growth and sustainable development is significantly dependent on the implementation of mixed transport, which involves the integrated use of different modes of transport in one transport system. The feature of intermodal transportation is the use of the benefits of each mode of transport. The criteria for efficiency are not only the cost of delivery, but also the speed, accuracy of delivery, as well as environmental safety and many other factors.

The modern concept of the development of European transport is based on the multimodal and intermodal approach, which involves coordinating the capacities of different modes of transport and time of transportation. The advantage of intermodal and multimodal transportation is the efficient combination of several modes of transport, optimization of transit time, reducing warehouse costs and controlling the cost of transport. As a result, due to the reduction of carbon emissions, the state of the environment is also improving [3] .

The legal basis for intra-modal carriages is: the UN Convention on International Multimodal Transport of Goods (1980); European Agreement on Important International Combined Transport Lines and Related Objects (ULKP / AGTC) of 01.02.1991. with the list of standards and parameters ("Yellow Book"); European Agreement on Important Inland Waterways of International Importance (UMVSH / AGN) of January 19, 1996; Protocol on combined transport by inland waterways to the European Agreement (ULKP / AGTC) of 17.01.1997; Association Agreement between Ukraine and the European Union [4].

Ukraine has virtually no legislative framework for multimodal transport. The consequences of this are close to zero level of multimodal and intermodal transport, first of all, container and low quality of transport infrastructure, which results in low efficiency of logistics, high transport component in the price of goods.

In Ukraine, the transport and logistics network of multimodal transportation is only being created. The most actively used are multimodal and intermodal carriage of goods using road, rail and sea transport. There is a gradual increase in the attraction to the abovementioned transportation of air transport.

The peculiarities of air and road transport for intermodal transport and their environmental impact are considered below.

Transport provides communications between industries, enterprises, regions of the country, foreign countries. Cargo turnover and volumes of cargo transportation for the first quarter of 2018 are given in Table 1 [5].

Road transport is one of the most important areas of entrepreneurial activity, as in the process of managing, each firm needs the transportation of materials, raw materials, finished products, while they use their own vehicles or use the services of motor transport enterprises. Automobile transport plays an important role in the socio-economic development of the country. 
Cargo turnover and volumes of cargo transportation in January-March 2018

\begin{tabular}{|l|c|c|}
\hline & Cargo turnover, mln. tkm & Volume of transported cargoes, mln. $\mathrm{t}$ \\
\hline Transport & $\mathbf{7 9 2 1 9 , 3}$ & $\mathbf{1 5 0 , 0}$ \\
\hline railway & 47261,0 & $\mathbf{7 9 , 1}$ \\
\hline automotive & 9611,9 & 39,6 \\
\hline water & 681,8 & 0,7 \\
\hline pipeline & 21602,0 & 30,6 \\
\hline aviation & 62,6 & 0,02 \\
\hline
\end{tabular}

Today, more than 100 thousand road carriers provide transportation services for $52 \%$ of passengers and $64 \%$ of goods [6]. Its features are flexibility and adaptability to user requirements. The high level of competition in the industry, the small size of most motor transport enterprises, work mainly with small batches of goods, as much as possible orient the motor transport business for the needs of a particular client. Therefore, road transport has become the dominant type of inland transport in most developed countries.

At the same time, motor transport is one of the main pollutants of atmospheric air. The main component of the negative impact on the environment in the functioning of motor transport is associated with environmental pollution by harmful substances, noise and products of wear. The main harmful substances that pollute the atmosphere are: carbon monoxide; hydrocarbons, including those having carcinogenic properties; nitrogen oxides; solid particles and soot; dioxide of sulfur; lead compounds. In addition, concerns are raised about the increase in carbon dioxide concentrations in the atmosphere resulting from the combustion of extractive fuels, resulting in an increased greenhouse effect, which can lead to unpredictable climatic and consequently economic and social consequences. Its emissions of pollutants to the atmosphere in recent years make up about 1796.5 million tons annually or $90 \%$ of the total emissions of pollutants from mobile sources of pollution in Ukraine (Fig. 1).

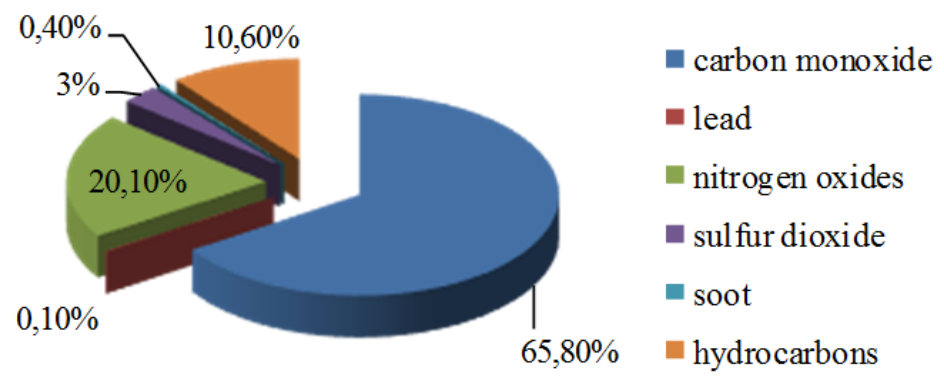

Fig. 1. Composition of exhaust gases of the car

During the operation of motor vehicles, air pollutants are significantly contaminated with solids used for the production of tires. These are isoprene, chloroprene, acrylate and other rubber. As a result of intense movement, the wear of asphalt coatings is increasing, which increases the content of solid particles in the air, including carcinogens. Various mineral salts (sulfates, chlorides and others), which are used on roads during ice-cold, wash off from the roads fall into the soil and reservoirs, cleansing and mineralizing them. The wastewater of the motor transport enterprise, which is polluted by the worked oil products, oils, etc., causes significant losses to the environment. Polluting media used during repair, maintenance and refueling. Toxic are lubricants (motor, transmission, etc.) and mineral-based liquids used for hydrosystems, adhesives and sealants on the basis of formaldehyde and epoxy resins, which are used in the repair and manufacture of 
cars. Cooling and brake fluids are poisonous. It is known that the share of transport in the total amount of emissions of harmful substances in the atmosphere from stationary and mobile sources is about $70 \%$, which exceeds the share of any other type of economic activity. In general, according toautomobile engines in Ukraine burn around 2 billion tons of fuel each year. In internal combustion engines, the burning of 1 ton of gas consumes about 15 tons of air, or 2000 liters of oxygen, which is 2.5 times more than its daily consumption by a person. When burning 1000 liters of fuel, the carburetor emits $200 \mathrm{~kg}$ of carbon monoxide (CO), $25 \mathrm{~kg}$ of hydrocarbons, $20 \mathrm{~kg}$ of nitrogen oxides, $1 \mathrm{~kg}$ of sulfur oxides and $1 \mathrm{~kg}$ of soot. In addition to environmental problems, the economic and social aspects of the functioning of the transport system as an element of the logistics system of the enterprise are equally important.

The features of intermodal transportation for air transport are considered below.

Air transport is one of the youngest and most powerful types of communication. Its advantages are speed, year-round functioning, the ability to deliver goods in hard-to-reach areas. Air transport carries out the overwhelming majority of transcontinental passenger transportation and transportation of goods with a short shelf life for considerable distances.

For the EU, air transport is very important, since it employs 5.1 million workers and accounts for $2.4 \%$ of the gross domestic product (GDP) of the EU (or $€ 365$ billion). Air transport occupies a leading place in the transport of passengers and cargo and promotes economic development, international trade, and opened new markets, especially in the peripheral regions of the EU [7]. In recent decades, their global volume has steadily increased, each year ranging from 5 to $7 \%$. Ukraine has air connections with many countries, which contributes to the development of intermodal transport. There was a reorientation of passenger flows from domestic to international flights. At present, they account for about $60 \%$ of all passenger traffic. Indicators of Ukrainian airlines are shown in Table 2.

In 2017, passenger and cargo transportation was carried out by 32 companies. 10555,6 thousand passengers and 82,8 thousand tons of cargoes were transported (a decrease from 27,6\% and $11,4 \%$, respectively, from 2016 ) [8].

Table 2

Indicators of activity of Ukrainian airlines for the period from 2009 till 2016

\begin{tabular}{|c|c|c|c|c|c|c|c|c|c|}
\hline & \multicolumn{9}{|c|}{ Total } \\
\hline & $\begin{array}{c}\text { Units of } \\
\text { measurement }\end{array}$ & 2009 & 2010 & 2011 & 2012 & 2013 & 2014 & 2015 & 2016 \\
\hline 1 & 2 & 3 & 4 & 5 & 6 & 7 & 8 & 9 & 10 \\
\hline $\begin{array}{l}\text { Passengers } \\
\text { transported }\end{array}$ & $\begin{array}{l}\text { thous. } \\
\text { people. }\end{array}$ & 5131,1 & 6106,5 & 7504,8 & 8106,3 & 8110,4 & 6472,2 & 6304,3 & 8277,9 \\
\hline $\begin{array}{l}\text { Passenger- } \\
\text { kilometers } \\
\text { completed }\end{array}$ & $\begin{array}{l}\text { billion } \\
\text { pass-km }\end{array}$ & 9,0 & 11,0 & 13,8 & 14,4 & 12,6 & 11,6 & 11,4 & 15,5 \\
\hline $\begin{array}{l}\text { Cargo and mail } \\
\text { transported }\end{array}$ & thous. $t$ & 85,1 & 87,9 & 92,1 & 122,6 & 99,2 & 78,7 & 70,6 & 74,3 \\
\hline $\begin{array}{l}\text { Performed ton- } \\
\text { kilometers }\end{array}$ & $\mathrm{mln} . \mathrm{tkm}$ & 350,9 & 379,1 & 370,6 & 363,1 & 273,1 & 239,3 & 218,5 & 226,4 \\
\hline \multirow[t]{2}{*}{$\begin{array}{l}\text { Commercial } \\
\text { flights } \\
\text { performed }\end{array}$} & thous. & 84,2 & 98,9 & 105,3 & 106,1 & 96,0 & 74,8 & 66,3 & 79,5 \\
\hline & \multicolumn{9}{|c|}{ International } \\
\hline $\begin{array}{l}\text { Passengers } \\
\text { transported }\end{array}$ & $\begin{array}{l}\text { thous. } \\
\text { people. }\end{array}$ & 4135,9 & 5144,3 & 6328,5 & 6820,9 & 6900,3 & 5828,6 & 5679,6 & 7475,4 \\
\hline
\end{tabular}


Table 2 continue

\begin{tabular}{|l|c|c|c|c|c|c|c|c|c|}
\hline \multicolumn{1}{|c|}{1} & 2 & 3 & 4 & 5 & 6 & 7 & 8 & 9 & 10 \\
\hline $\begin{array}{l}\text { Passenger- } \\
\text { kilometers } \\
\text { completed }\end{array}$ & $\begin{array}{c}\text { billion } \\
\text { pass-km }\end{array}$ & 8,4 & 10,4 & 13,1 & 13,7 & 11,9 & 11,3 & 11,1 & 15,2 \\
\hline $\begin{array}{l}\text { Cargo and mail } \\
\text { transported }\end{array}$ & thous. t & 84,4 & 87,5 & 91,9 & 122,0 & 98,8 & 78,2 & 70,2 & 74,1 \\
\hline $\begin{array}{l}\text { Performed ton- } \\
\text { kilometers }\end{array}$ & mln. tkm & 350,5 & 378,9 & 370,4 & 362,8 & 2792,9 & 238,9 & 218,3 & 226,2 \\
\hline $\begin{array}{l}\text { Commercial } \\
\text { flights } \\
\text { performed }\end{array}$ & thous. & 58,2 & 71,4 & 77,8 & 77,7 & 71,6 & 61,3 & 56,1 & 67,9 \\
\hline
\end{tabular}

Today, the rapid process of European integration and international environmental standards adopted by forcing enterprises aviation industry to step up its activities to reduce environmental impact. As a result, air transport is contamination of soil, water bodies and the atmosphere, and the specifics of the impact of air transport on the environment found in significant noise performance and significant emissions of various pollutants. It is important to draw attention to the fact that the negative impact of air transport is not limited only to the emission of $\mathrm{CO}_{2}$ into the atmosphere and the creation of a high level of noise, which is harmful to the health of the population and leads to environmental pollution, and its functioning is primarily due to the use of significant volumes of various resources, in particular natural (Fig. 3).

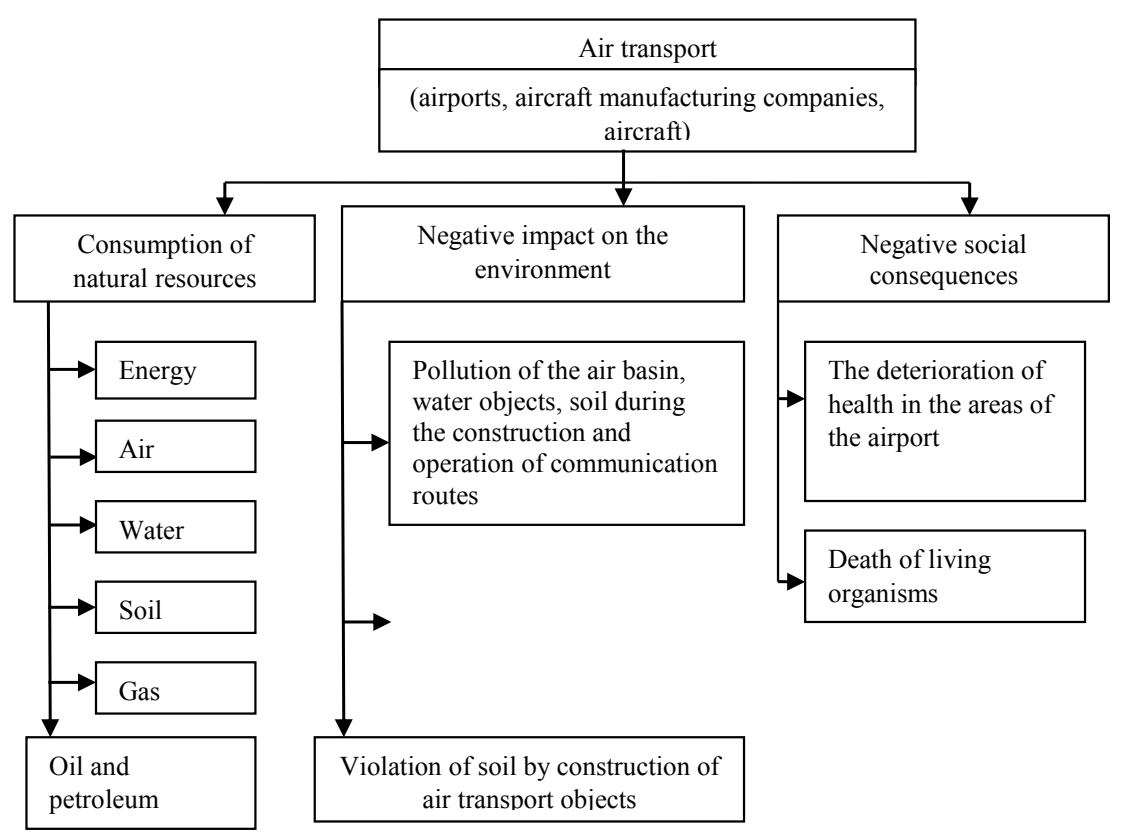

Fig. 3. Influence of air transport on the environment

Aviation transport causes «damage» to nature and population, with a significant proportion of pollution being attributed to airports. For example, flying planes emit thousands of tons of harmful emissions into the atmosphere, with their largest volume coming to take off and the altitude, which indicates their significant concentration in the surrounding areas of the airport, where people live. The share of the total $\mathrm{CO}_{2}$ emissions from air transport is $2 \%$. Rapid 
development of air transport would inevitably cause enormous damage to the environment, but the initiatives that are being implemented by the industry are intended to stabilize, and then reduce noise levels and emissions of greenhouse gases. According to the experts of the world, in order to reduce the noise load and $\mathrm{CO}_{2}$ emissions, it is necessary to develop the appropriate airport infrastructure, which will eliminate the above-mentioned problems and enable the rapid maintenance of various types of aircraft. The contribution of such measures is estimated by analysts as less significant than the contribution to the renewal of the park and the use of biofuels (about $10 \%)$.

It was determined that aviation transport contributes significantly to the emission of greenhouse gases in the upper atmosphere. Flying at high altitudes and at high speeds results in the dissipation of combustion products, which affects climate change more than other modes of transport. The impact of air transport on the environment is due to the following features of aviation activity: the modern fleet of aircraft and helicopters has gas turbine engines operating on aviation aircraft, the chemical composition of which differs from automotive gasoline and diesel fuel of better quality with a lower content of sulfur and mechanical impurities, the main mass the exhaust gases emitted by aircraft directly in the airspace at relatively high altitudes, at high speed and turbulent flow, and only a small fraction - in the vicinity of airports and settlements. An important problem is the noise of airplanes in the airport area. Factors of the adverse impact of aviation on the environment are noise during the operation of airplanes, emissions of pollutants, electromagnetic radiation, thermal pollution, contaminated drains from the airport [9].

Consequently, an increase in the volume of air transportation in the world leads to the need for effective approaches. It should be noted that Environmental protection is one of the strategic objectives of the International Civil Aviation Organization (ICAO), whose main objective is to reduce the negative impact of global civil aviation on the environment:

- limiting or reducing the number of people suffering from significant noise caused by aviation activities;

- limiting or reducing the impact of aviation emissions on air quality;

- limiting or reducing the impact of aviation emissions of greenhouse gases on the global climate.

Thus, today there are many approaches and methods to minimize the impact of transport activities on the environment, of which the most effective are:

- use of environmental vehicles with electric, gas, hydrogen and hybrid engines, as well as ecological fuel and lubricants;

- driver training, energy efficient driving;

- optimization of routes taking into account the environmental impact;

- an increase in the share of rail and water transportation;

- implementation of schemes of multimodal transportation using mainly rail and water transport, as these transport modes are less harmful to the environment;

- the use of trailers with bunk trailer, and the loading of containers in two tiers, which allows us to rationally use the space of rolling stock and a smaller number of vehicles;

- the use of environmentally friendly loading and unloading equipment.

The most effective approach is to apply a balanced approach to managing environmental impacts during transportation.

Thus, both automobile and aviation transport have a significant anthropogenic impact on the environment and public health. One of the measures to minimize such impact is the introduction of mixed traffic on the principles of environmental logistics. Analyze the existing approaches to the formation of logistics systems on the principles of minimizing environmental impact.

The main task of transport at the present stage is ensuring coordination of the various types of transport on a unified methodological basis; provision of demand for cargo transportation in conditions of system interaction of two or more types of transport; safety and quality of 
transportation; creation of conditions for financial and economic improvement of transport enterprises and intensification of investment activity; development of scientific and methodological and organizational and technical means of accompaniment of processes of transportation of cargoes under the conditions of interaction of various elements in the structures of logistics.

During the last decade, considerable experience has been gained in improving the general principles and mechanisms of enterprises with the use of logistics. In the writings of domestic and foreign economists, in particular VP Meshalkina, E.V. Mishenina, I.I. Koblianskaya VF Dmitrichenko, PP Levkovtsy, AM Tkachenko, O.S. Ignatenko, LG Zayonchyk, IM The author, K.Klarka, M. Porter, are investigating general theoretical and highly specialized problems of logistics. The literature review shows examples of effective solutions to certain environmental issues faced by modern logistics managers. Müller, for example, has shown the experience of using disposable plastic containers for packaging solid waste management at Proctor \& Gamble Company. Shelsey analyzed Canon's program for disposable cartridges for copiers, laser printers and fax machines. Others, such as Polen and Pharys, considered the logistics of channels and issues related to the recycling of plastic waste. Issues relating to the inclusion of an ecological component in the system of logistic management are considered in the works of Yu.V. Chortok, T.M. Skorobogatov, V.P. Mateichyk, V.O. Khrutba, V.I. Zuzjun. It should be noted that their research is most often concentrated within the framework of one functional area of logistics, for example, resource conservation.

Analysis and generalization of domestic and foreign approaches to the interpretation of the concept of "ecological logistics" has made it possible to establish that the scientists who are investigating this problem consider this concept to be largely limited, taking into account the ecological destructive effect of only certain subsystems of the logistic system or only the consequences of such influence. Chortok Yu.V. [10] proposed and theoretically substantiated the interpretation of the concept «ecological logistics» as a subsystem of management of material and associated flows from the primary source to the final consumer, which provides minimization of environmental degradation effects on the environment. This interpretation enables to substantiate the necessity of forming an ecological and economic management mechanism as a macro-logistic system of the city (region) and the micro-logistic system of the transport enterprise. For all levels of drug management it is expedient to consider the following tasks:

- to conduct a permanent audit of carbon emissions in the supply chain;

- transfers of goods mainly to the «green» mode of transport;

- development of «green» vehicles, air and sea vessels;

- reducing environmental impacts during storage;

- increase of ecological efficiency of fuel at cargo and passenger transportations;

- introduction of reverse logistics of waste management;

- creation of a sustainable logistics system of the city;

- state support for the stability of the logistics system.

The experience of well-known companies convincingly proves the high effectiveness of these measures in practice. Thus, Unilever, due to multimodal transportation (reducing road haulage and increasing the share of rail and sea traffic), significantly reduced the level of greenhouse gas emissions and reduced the amount of transport costs. The Japanese shipping company $\mathrm{K}$ Line has installed on a separate court a computer system that, on the basis of continuous monitoring of weather and hydrographic conditions, optimizes engine operation, which in turn allows reducing emissions of harmful emissions to the atmosphere by $1 \%$. The world-renowned express delivery company DHL has developed a service, in the process of implementation customers are being asked to assume responsibility for environmental pollution. The GoGreen service allows you to calculate the amount of $\mathrm{CO}_{2}$ emissions when transporting cargo from the moment it is accepted by the transport company and until delivery to the recipient. The consumer voluntarily decides to pay additional costs for environmental damage. 
The issue of taking into account the full economic and environmental value of transport services is a complex multivariant problem, which involves a comprehensive accounting of economic costs and environmental losses in the logistics system. This approach takes into account the unity of the processes of nature management, consumption of natural resources and the amount of waste that is formed in this case. Below the peculiarities of applying ecological logistics approaches in intermodal traffic are considered.

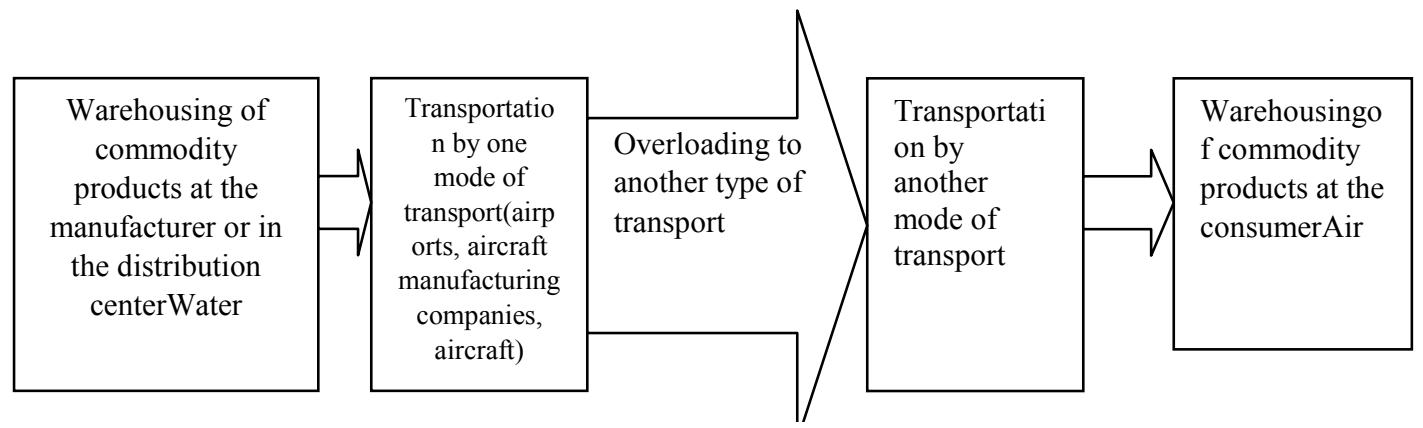

Fig. 4. Logistics chain in intermodal transportation

Transportation is a key integrated component of any process of production or consumption, essence of which is connected with the movement of material resources and finished products by vehicles in the logistics chain. Logistics chain in intermodal transportation includes such processes (Fig. 4).

The conducted researches have determined that modern transportation, in most cases, is a complex object of interaction in the market of transport services. The most frequent cases are the cases of interaction of consumers (senders) of goods with one or two modes of transport (aviation automobile, railway - automobile, sea (river) - automobile, etc.). The block diagram of the interaction of aviation and automobile type of transport is presented in Fig. 5.

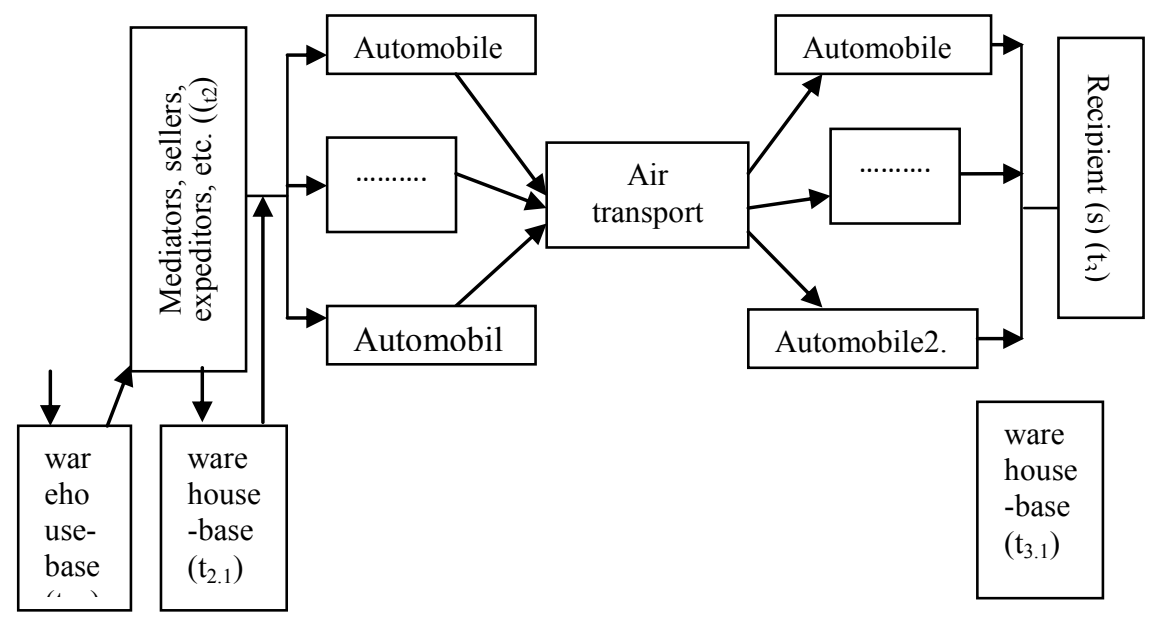

Fig. 5. Structural diagram of interaction of aviation and automobile type of transport

From Fig. 5 it is evident that when using two types of transport, a linear scheme of interaction is implemented, which enables to effectively implement environmental principles in the 
formation of the logistics system of transportation. Assessment of environmental impacts is carried out for each element of the logistics chain.

We will form a system model for the ecological assessment of the logistic system for intermodal transportation, which is a rolled-up tree of an excessive set of tasks and procedures that can theoretically be carried out in the logistic processes of intermodal transport. The overall assessment of the logistic system for intermodal traffic $\left(L S_{I \Pi}\right)$ can be represented by the function:

$$
L S_{I I T}=f\left(W_{\text {ВИР }}, W_{\text {СКЛАД }}, W_{\text {ТРАНС.АВТ. }}^{\prime}, W_{\text {ТРАНС.ЛIT }}, W_{\text {ТРАНС.АВТ. }}^{\prime \prime}, W_{\text {СКЛ.ЗАМОВН. }}\right),
$$

where $W_{\text {ВИР }}=f\left(x_{i}\right)$ - the subsystem of production (goods); $W_{\text {СКЛАД }}=f\left(x_{j}\right)$ - subsystem of storage of products and goods; $W_{\text {TPAHC.ABT. }}^{\prime}=f\left(x_{k}\right)$ - subsystem of transportation by car; $W_{\text {TPAHC.ЛITAK }}=f\left(x_{n}\right)$ subsystem of transportation by airplane; $W_{T P A H C . A B T .}^{\prime \prime}=f\left(x_{m}\right)$ - subsystem of transportation by car; $W_{\text {СКл.зАмовн. }}=f\left(x_{l}\right)_{-}$subsystem storage of products and goods from the customer; $x_{i}, x_{j}, x_{k}, x_{n}, x_{m}, x_{l}-$ economic and environmental indicators of the system; $i, j, k, n, m, l-$ number of parameters in each subsystem.

The effectiveness of each subsystem is estimated by the local integrated indicator, the effectiveness of the entire drug is determined on the basis of a cumulative approach, taking into account the significance of each subsystem.

$$
\begin{aligned}
& L S_{\text {III }}=W_{\text {ВИР }} \cdot \alpha_{1}+W_{\text {СКЛАД }} \cdot \alpha_{2}+W_{\text {ТРАНС.АВТ. }}^{\prime} \alpha_{3}+W_{\text {ТРАНС.ЛIT. }} \cdot \alpha_{4}+W_{\text {TРАНС.АВT. }}^{\prime \prime} \cdot \alpha_{5}+ \\
& +W_{\text {СКЛ. ЗАМОВН. }} \cdot \alpha_{6}
\end{aligned}
$$

The ecological-economic assessment of the logistic system involves solving the multicriterial optimization problem with two targeted functions - minimizing the negative impact on the environment with maximizing the economic efficiency of logistic processes in intermodal transport:

$$
W_{i}=\min \max y_{1_{i}}\left(y_{2_{i}}\right) \text {, }
$$

where $W_{i}$ - the minimax optimization criterion of $i$-th subsystem; $y_{1 i}$ - the environmental criteria of minimization of $i$-th subsystem; $y_{2 i}$-the economic criteria of maximization.

The target function for the $i$-th subsystem of the ecological assessment of the logistic system for intermodal transportation is [29]:

$$
W_{i}=\left\{\begin{array}{l}
y_{i}^{1}=\sum_{k=1}^{m} c_{k_{i}} \cdot x_{k_{i}} \rightarrow \min , \\
y_{i}^{2}=\sum_{k=1}^{m} d_{k_{i}} \cdot x_{k_{i}} \rightarrow \max
\end{array},\right.
$$

With restrictions: 


$$
\sum_{i=1}^{m} \sum_{i=1}^{n} a_{i j} \cdot b_{i j} \cdot x_{i j}^{\prime}<l_{i j}, \quad x_{i j}^{\prime}>0
$$

where $y_{i}{ }_{i}, y_{i}{ }_{i}$ - ecological and economic efficiency of the $i$-th subsystem of the logistic system of intermodal transportation; $C_{k}, d_{k i}$, environmental and economic indicators; $X_{k i}$ - input parameters of the $i$-th subsystems; $X_{I j}^{\prime}$ - amount of $j$-type of waste of the $i$-th subsystem; $m$ - number of subsystems EOLS; $n-$ quantity of ecological influences in the system; $a_{j}, b_{j}$ - correction coefficients of environmental impacts; $l_{j}-$ maximum permissible and normative ecological indicators.

Determination of optimization parameters of the logistic process will allow to ensure efficient organization of the process of delivery of goods by various modes of transport (intermodal) transportation. The choice of one or another type of transport is due to the relevant criteria, types of goods and other factors that arise in the process of transportation processes.

It is also necessary to take into account that in the case of intermodal transport of goods, two variants of technological processes can be implemented: using the composition (base) between the various transport links and without the use of the latter, which imposes additional tough conditions on the formation of consignments and the work of the respective modes of transport. The conducted studies have shown that the implementation of the above-mentioned options significantly different in terms of cost and performance of transportation and requires the setting and solution of optimization tasks of the logistics system.

Thus, the creation of a logistic system of intermodal transportation taking into account environmental impacts will allow:

- reduce emissions of harmful substances into the atmosphere through the transition to more environmentally friendly modes of transport and vehicles using less fuel, replacing fuel for less harmful;

- reduce costs of material, information and transport flows during transportation;

- take into account environmental factors when placing warehouses;

- minimize material resources when packaging products;

-implement waste recycling systems, reduce the amount of waste generated by the enterprise;

- to finance environmental protection measures in order to create a favorable image for consumers and counteragents, etc.

The obtained scientific results allow to formulate the concept of «Balanced approach» in the organization of intermodal transportation, aimed at increasing volumes of transportation, profit, profitability, reducing the cost of developing a clearly defined business strategy with minimizing human impact on the environment.

Such measures have four main components and require careful assessment of all possible options for reducing environmental impacts, both from road and air transport, including:

- reduction of atmospheric emissions from transport sources,

- planning and use of territories

- technical measures to mitigate environmental impacts,

- operating restrictions, in compliance with the relevant legal obligations and existing agreements, current legislation and implemented strategies.

«Balanced Approach» is an important step towards reducing the level of anthropogenic impact of logistics processes. However, in order to achieve effective and sustainable reduction of environmental damage, it is also necessary to apply more stringent technical standards, such as more stringent environmental requirements, along with measures to decommission obsolete vehicles. 
In the framework of a balanced approach, motor transport enterprises and airports are encouraged to first assess the current environmental situation by identifying specific issues using simulation (computer simulation) and monitoring methods. In order to implement effective intermodal transportation for transport enterprises, the following basic elements should be fulfilled:

1. Reducing individual anthropogenic influences through the promotion and support of research, research and technological programs aimed at reducing impacts on the source or other means.

2. Land-use planning and management policies to prevent inconsistent development in sensitive areas. This action combines planning (zoning, easement), mitigation (building codes, isolation, disclosure of real estate information) and financial aspects (tax breaks, fees).

3. Practical application of operating procedures to reduce the harmful effects of transport activities, as far as possible, without affecting safety. These procedures allow to reduce or redistribute environmental damage both in the roadside and in the aerodrome environment.

4. Operating restrictions for a car and aircraft are defined as any limitation related to the environmental consequences. It is used only after considering other elements of the balanced approach. In connection with this, there is a need to address the urgent environmental problems of all spectrum of transport, production, intellectual and social activities at the expense of state and sectoral systems of environmental management.

\author{
PEФEPAT \\ Вікторія Хрутьба ${ }^{l}$, Василь Матейчик', Оксана Спасіченко ${ }^{l}$, Світлана Марунич ${ }^{2}$ \\ ${ }^{I}$ Наиіональний транспортний університет,Viktoriia.Khrutba@gmail.com,wmate@ukr.net, \\ Oxanasp@ukr.net, \\ ${ }^{2}$ Управління стратегічного розвитку Державної авіачійної служби України, \\ Svitlana.Marunych@avia.gov.ua
}

\title{
ЕКОЛОГІЧНИЙ ПІДХІД ДО ОЦІНКИ ВПЛИВУ ТРАНСПОРТУ НА НАВКОЛИШНЕ
} СЕРЕДОВИЩЕ ПРИ ІНТЕРМОДАЛЬНОМУ ПЕРЕМІЩЕННІ

Сучасна концепція розвитку європейського транспорту заснована на мультимодальному та інтермодальному підходах та передбачає координацію дій різних видів транспорту. Екологічноорієнтований транспортний менеджмент забезпечує мінімізацію впливу на навколишнє середовище для інтермодальних перевезень.

Метою статті є розроблення принципів екологічної логістики в інтермодальних перевезеннях для зменшення впливу транспортної діяльності на навколишнє середовище.

Для досягнення поставленої мети було поставлено такі завдання: охарактеризувати умови здійснення міжміського транспорту; визначити особливості використання авіаційного та автомобільного транспорту та їх вплив на навколишне середовище; проаналізувати підходи до формування логістичних систем на принципах мінімізації впливу на навколишнє середовище; сформувати принципи створення екологічно орієнтованої логістичної системи для інтермодального транспорту.

Ключові слова: інтермодальний транспорт, логістична система, автомобільний транспорт, авіаційний транспорт.

\footnotetext{
PЕФЕРАТ

Виктория Хрутьба ${ }^{l}$, Василий Матейчик ${ }^{1}$, Оксана Спасиченко ${ }^{l}$, Светлана Марунич ${ }^{2}$,

${ }^{1}$ Hаџиональный транспортный университет,Viktoriia.Khrutba@gmail.com,wmate@ukr.net, Oxanasp@ukr.net,

${ }^{2}$ Управление стратегического развития Государственной авиачионной службы Украины, Svitlana.Marunych@avia.gov.ua
}

ЭКОЛОГИЧЕСКИЙ ПОДХОД К ОЦЕНКЕ ВЛИЯНИЯ ТРАНСПОРТА НА ОКРУЖАЮЩУЮ СРЕДУ ПРИ ИНТЕРМОДАЛЬНОМ ПЕРЕМЕЩЕНИИ

Современная концепция развития европейского транспорта основана на мультимодальном и интермодальном подходе и предполагает координацию действий различных видов транспорта. 
Экологически ориентированное управление транспортом обеспечивает минимизацию воздействия на окружающую среду для интермодальных перевозок.

Целью статьи является разработка принципов экологической логистики в интермодальных перевозках с целью снижения воздействия транспортной деятельности на окружающую среду.

Для достижения этой цели были сформированыследующие задачи: охарактеризивать условия осуществления меж / смешанных перевозок; определить особенности использования авиационного и автомобильного транспорта и их воздействия на окружающую среду; проанализировать подходы к формированию логистических систем на принципах минимизации воздействия на окружающую среду; сформировать принципы создания экологически ориентированной логистической системы для интермодальных перевозок.

Ключевые слова: интермодальные перевозки, логистическая система, автомобильный транспорт, авиационный транспорт.

\author{
ABSTRACT \\ Viktoria Khrutba ${ }^{1}$, Vasyl Mateichyk ${ }^{1}$, Oksana Spasichenko ${ }^{I}$, Svitlana Marunych ${ }^{2}$ \\ ${ }^{1}$ National Transport University,Viktoriia.Khrutba@gmail.com,wmate@ukr.net, Oxanasp@ukr.net, \\ ${ }^{2}$ Development and Environmental Safety Airports Division of State Aviation Administration, \\ Svitlana.Marunych@avia.gov.ua

\section{ECOLOGICAL APPROACH TO EVALUATION OF THE EFFECTS OF TRANSPORT} \\ ON ENVIRONMENT IN INTERMODAL TRANSPORTATION
}

The modern concept of the development of European transport is based on the multimodal and intermodal approach and involves coordinating the actions of various modes of transport. The ecologicallyoriented transportation management ensures minimization of environmental impacts for intermodal transport.

The purpose of the paperis to develop the principles of ecological logistics in intermodaltransportation in order to reduce the impact of transport activities on the environment.

Following tasks has been formedto acheive the goal: to characterize the conditions of implementation of inter / multimodal transportation; to determine the peculiarities of the use of aviation and road transport and their impact on the environment; to analyze approaches of forming logistics systems on the principles of minimizing the impact on the environment; to form the principles of forming an ecologically oriented logistics system for intermodal transportation.

Key words: intermodal transportation, logistics system, road transport, aviation transport.

\title{
REFERENCES
}

1. Approval of the Transport Strategy of Ukraine for the period up to 2020: Order of the Cabinet of Ministers of Ukraine dated October 20 [Electronic reference]. - 2010. - N 2174-p. Kiev. - Access mode: http://zakon4.rada.gov.ua / laws / show / 2174-2010-\% D1\% 80 - Title from the screen.

2. Khrutba V.O. Implementation of ecological logistics as a component of sustainable transport development / V.O. Khrutba, V.P.Mateichyk, M.Smeshek // Transport problems. - Iss. 8. - 2011. - P. 217-224.

3. The ways of development of multimodal (combined) transportations in Ukraine. Analytical note. National Institute for Strategic Studies [Electronic reference]. - Access mode: www.niss.gov.ua/articles/599/ - Title from the screen.

4. Malakhova O. A. Problems of the development of the international transport system in the conditions of improvement of intermodal transportation / O. A. Malakhov, M. I. Selesh. [Electronic reference]. - Access mode: http://repository.kpi.kharkov.ua/bitustream/hpi-press/ 29888/1 / vestik_KhPI_ 2009_8_ Malakhova_Problemy_rozvytku.pdf.

5. Official site of Derzhkomstat [Electronic reference]. - Access mode:

http://www.ukrstat.gov.ua/operativ/operativ2018/tr/vp/vp_u/vp0118_u.htm - Title from the screen.

6. Strategic plan for the development of road transport and road transport for the period up to 2020 Order of the Ministry of Infrastructure of Ukraine December 21. - 2015. - No. 548.

7. Eurostat (2015): Database: Overview of the air passenger transport by country and airports (avia_paoc) Luxembourg [Electronic reference]. - 2016. - Access mode: http://ec.europa.eu/eurostat/statisticsexplained/index.php/ Air_transport_statistics.

8. Official site of the Ministry of Infrastructure of Ukraine [Electronic reference]. - Access mode: https://mtu.gov.ua/content/statistichni-dani-v-galuzi-aviatransportu.html. 
9. Janic M. An Analysis of the Concepts of Airport Sustainable Capacity and Development / M. Janic // Ist Intern. Conf. "Environmental Capacity at Airports". - The Manchester Metropolitan University. - Manchester, Great Britain. 2nd and 3rd Apr., 2001. - P. 1-20.

10. Green logistics. Improving the environmental sustainability of logistics / Alan McKinnon, Sharon Cullinane, Michael Browne, Anthony Whiteing. - London: Chartered Institute of Logistics and Transport, 2010. $-372 \mathrm{p}$.

DOI: doi.org/10.18372/38211

UDC: 502.175:629.3.015.6:656.1(045)

\title{
3.5 NOISE MONITORING FOR IMPROVEMENT OF OPERATIONAL PERFORMANCES OF THE AIRCRAFT IN VICINITY OF AIRPORTS
}

\author{
Mikhal Bukalal, Oleksandr Zaporozhets ${ }^{2}$, \\ Volodymyr Isaienko ${ }^{3}$, Andrzej Chyla ${ }^{l}$
}

The aircraft noise is usually the single or somewhere one of the most important local impact factor arising from airport operations which, unless managed effectively, has the potential to constrain the ability of airports to grow in response to demand and hence limit the social and economic benefits that future growth could bring [1]. People living around the airports are driven to complain when some nuisance factor (or stressor) in the environment gives rise to annoyance and/or sleep disturbance when this stressor reaches a threshold of tolerance. Polish Environmental Protection Law (EPL) [2] treats noise as an environmental pollution, hence this Act adopts the same general principles, obligations and forms of proceedings in relation to noise, as to other areas of environmental protection. The EPL also introduces to the legal system of environmental protection a new institution of the so-called noise areas - the areas where the noise level is exceeded to the extent that it requires corrective action via the recovery programs.

According to art. 179 of the EPL, airports are included in list of objects, whose operation may cause a negative acoustic impact on environment in significant areas, and the manager of such airport is obliged to draw up acoustic maps of the area every 5 years, during which the operation of the airport may exceed permissible noise levels for the environment. As required by EPL to control the impact of aircraft noise on population an area of limited usage (noise zone or obszar ograniczonego użytkowania in Polish - OOU) is created around any airport in Poland. This area arises when, from an ecological review or from an environmental impact assessment, required by the provisions of the Polish Act of 3 October 2008 on access to information about the environment and its protection, public participation in environmental protection and environmental impact assessments, or post-implementation analysis shows that despite the use of available technical, technological and organizational solutions, environmental quality standards outside the airport area can not be met.

Noise from the aircraft is limited by ICAO standards [3] and due to corresponding Polish Aviation Law, art. 53.1 [4] in the scope not reserved for EASA, the President of the Office shall examine compliance with the requirements to be met by aircraft in the scope of environmental protection against noise and pollution of land, water and air, as defined in international regulations and European Union law and regulations issued on based on paragraph 5. Regulation (EC) No 216/2008 of the European Parliament and of the Council of 20 February 2008 on common rules in the field of civil aviation and establishing a European Aviation Safety Agency EASA states that all aircraft (except aircraft specified in Annex II w / in regulation), they must meet the environmental protection requirements for noise in accordance with Annex XVI of the Convention on International Civil Aviation, December 7, 1944, also known as the Chicago Convention [3]. Meeting these requirements is confirmed by the Civil Aviation Office by issuing a noise certificate. 